\title{
Young Consumers' Fashion Brand Preferences. An Investigation among Students in Romania
}

\author{
Laura NISTOR \\ Sapientia Hungarian University of Transylvania \\ Cluj-Napoca, Romania \\ e-mail: nistorlaura@uni.sapientia.ro
}

\begin{abstract}
The literature contends that youth are particularly fashion- and brand-sensitive, and they mostly prefer fast fashion brands; however, up to now, there has been little empirical data regarding Romanian youth's fashion brand preferences. In order to fill this gap, the article presents the results of an exploratory research based on mixed methodology which was realized among students in Cluj-Napoca, Romania in connection with their fashion brand preferences. The online survey showed that a little more than half of the students do have a preferred fashion brand, and these are indeed mostly fast fashion brands. However, taken relatively, i.e. compared to other cues, the brand of the apparel is less important for the students. The most brandsensitive individuals are those who are fashion involved, early adopters of trends, and less price-sensitive. The narratives of the focus-group research enriched the insight about students' brand preferences.
\end{abstract}

Keywords: brand, fast fashion, students, convenience sample

\section{Introduction}

The literature (e.g. Parment, 2013) contends that millennials (i.e. generation Y, those born between 1981-1995 - e.g. Howe-Strauss, 2000) and post-millennials (i.e. generation Z, those born between 1996-present) can easily handle various products and huge amounts of product-related information. Youngsters are early adopters of fashion, and new products and brands have an important role in their identity construction and status consumption. Millennials were early socialized into a materialistic and consumer culture; designer brands and the ability to spend money on them was a constitutive element of millennials' status quo; the transformation of retail from a utilitarian project into a complex form of entertainment, as well as the multiplication of product and lifestyle choices through digital media and globalization, enabled the development of a different 
consumer and shopping culture in the case of the millennial and post-millennial generation (Bakewell-Mitchell, 2003).

Pentecost and Andrews (2010) found that digital media favours the early development of fashion-related concerns and enables the development of a pro-consumption attitude among youth. Youngsters are more worried than other generations about how others perceive them and use fashion as a tool for creating particular identities. This is a generation which wants the latest trends instantly, and so it represents a fruitful market for fast fashion products (Yarrow-O'Donnell, 2009).

It would be, however, premature to conclude that young consumers are nothing more than brand enthusiasts. Segran (2016) contends that youngsters are sceptical and sometimes even resistant towards brands and advertising in general and are disposed towards checking brand- and product-related information on social media via word-of-mouth marketing (see also Knittel et al., 2016).

While we have an extensive set of international studies regarding millennials' attitudes and practices in connection with fashion brands, there are only sporadic data regarding East-Central European and, particularly, Romanian youth. Based on these, we can articulate that Romanian youngsters are sensitive towards fashion brands (Sandu et al., 2014). The purpose of my study was to bring some clarifications about young Romanian consumers' fashion brand preferences. My aim was to understand which are the most preferred fashion brands by youngsters and how important is the brand of the clothing relative to other product characteristics. Additionally, I was interested in the ways in which youngsters articulate their relationship with fashion brands, how they emphasize in narratives their brand preferences or brand avoidance.

I relied on a mixed methodology which was based on an online questionnaire and on focus groups. The research was undertaken among the students of BabeşBolyai University (Cluj-Napoca, Romania) on the basis of a convenience sample in the period of $2017-2018$.

\section{The Role of Fashion Brands}

In the context of today's consumer society, brands represent signs, i.e. visual and symbolic messages about the products; brands are no longer used solely to differentiate among various products but to help consumers create specific identities through the usage of branded products (Franzen-Moriarty, 2009). To use Batey's (2008) words, brands and brand images provide specific feelings and messages to the consumers. Then, consumers choose specific products, brands, etc., i.e. specific signs (cf. Baudrillard, 1998) in order to construct, keep, and manage their identities and social positions. Fashion plays a crucial role here since it is "one of 
the most visible forms of consumption" (Crane, 2000: 1). Clothing helps people to choose specific identities and to place themselves either within specific groups (i.e. affiliation) or, on the contrary, against specific groups (i.e. distinction - Crane, 2000).

Fashion brands that signify specific social status or lifestyle can enable the entry into groups that value such brands. The role of fashion brands is particularly articulated in the case of young consumers. Young people's clothing choice is motivated by various aspects: they seek individuality and prestige as well as functionality, and, given their continuous online presence, they are very much influenced by trends (Fernandez, 2009). For youngsters, acceptance and assimilation into groups is very important, so they seek to wear clothes through which they are accepted by their peers (Fernandez, 2009). It is documented that millennials' and Generation Z members' preoccupation with their appearance results in high brand knowledge and in a receptive public towards innovations, which are accompanied by the need for instant gratification.

In the context of fashion brands, we must mention the growing importance of fast fashion brands. Fast fashion refers to low-cost clothing collections which are based on current high-cost luxury fashion trends (Fletcher, 2008). Fast fashion means a short time gap between production and distribution and provides fashionable, relatively cheap yet not necessarily high-quality clothes (Gabrielli et al., 2013). Fast fashion has a fast response to current trends and encourages disposability (Joy et al., 2012). It is a McFashion (Joy et al., 2012) which provides "trendier, must-have fashions which lure consumers into paying full price now rather than deferring gratification until the year-end sales arrive” (p. 275). The availability of relatively cheap, trendy clothes is very appealing especially to young people. Vice versa, fast fashion marketing targets mostly the youngsters aiming for instant gratification (Barton et al., 2012). Fast fashion products offer immediate gratification and happiness to consumers, and so hedonist lifestyles are one of the motors of fast fashion brand consumption (Miller, 2013). Fast fashion items respond to postmodern consumers' needs in terms of self-expression: such products offer freedom, fun, and pleasure for the consumers and, even if they are of lower quality as far as they can be combined in various creative forms, are suitable for expressing various forms of identity (Gabrielli et al., 2013).

Other authors approach the problem of fashion, fast fashion, and accumulation of clothing items from the perspective of showing off, i.e. materialism. Roberts and Jones (2001 - qtd by Goldsmith et al., 2012) consider that those who have a positive attitude towards material products use fashion items as instruments for showing status; materialistic values lead students to purchase a larger quantity of (branded) clothing because in this way they perceive that they can better signal their social position to others.

Goldsmith et al. (2012: 105) contend that brand engagement means "gratification through the acquisition of specific, branded goods that express some important 
element of the self", and, while the concept is usually quoted in relation with luxury consumption, in the case of students or less developed economies (i.e. publics with limited incomes), even fast fashion brands can have the function of signalling social status. Rhee and Johnson (2012) also contend that youngsters use apparel brands in order to display and communicate positive messages about themselves, and in this respect the influence of the social groups is decisive: group members usually choose to wear a certain brand because in this way they seek group acceptance; that is the reason - the authors conclude - why those consumers in whose cases self-monitoring is important are more predisposed towards wearing branded products.

Cardoso et al. (2010) found that consumers perceived specific brands as having specific identities, and they consumed those brands which were in accordance with their self-image. Concerning the relative importance of brands, we can quote, among others, the study of Kelemen-Erdős and Kőszegi (2017), which assessed the role of fast fashion brands in Hungarian young people's self-expression. The authors concluded that, indeed, brand has an important role in self-expression, but consumers attach different importance to brands. For self-expression and brand-engaged individuals, brands are the most important criterion of choice, but they are a minority group compared to the largest segment of the sample, i.e. the so-called rational consumers, who base their purchase decisions on other aspects than the brand of the product: for instance, they are more attentive to the price/ quality ratio of the products.

Regarding Romanian young consumers, we have only sporadic data in terms of fashion brand consumption. The 2014 survey on Romanian youth (Sandu et al., 2014) showed that having branded clothes is considered by Romanian young people a fashionable activity - hence, two-thirds of the respondents attached importance to branded clothes. In accordance with the need to have branded clothes, the same study showed that shopping for apparel was the most important spending activity for the youth. Spending on apparel corresponded to $175 \mathrm{RON} /$ month (approx. 40 EUR). The survey made among Romanian urbanites by Popa and Pelau (2016) showed also that young Romanian consumers are more sensitive towards branded clothes than older generations.

It seems that Romanian youngsters, similarly to their counterparts worldwide, are open-minded towards fashion and brand; they think that having branded clothes are important for self-esteem. At the same time, the preference for fashionable clothing is always put in balance with the price of the products. 


\section{Methodology and Research Questions}

My research aims at studying young Romanian consumers' fashion-related practices, attitudes, and discourses. The study is based on mixed methodology and combines the online survey with focus groups. By relying on a mixed-method strategy, I followed the recommendation of Kawamura (2011: 21) in connection with fashion- and dress-related studies. In the author's opinion on studying fashion, inductive strategies through qualitative methods help to "generate a theory during a study", while deductive approaches "provide a lens that shapes what is looked at and the questions asked".

Firstly, I relied on an online survey based on a convenience sample composed of students from Babeş-Bolyai University, Cluj-Napoca. Babeş-Bolyai University is the largest university in Transylvania, Romania. In spite of being nonrepresentative samples, convenience samples are widely used in social research (Gliner et al., 2009) because they provide "some" data, i.e. explorative facts in connection with the researched phenomena (Hill, 1998 - qtd by Sue-Ritter, 2012). On the other hand, college students are common subjects of consumptionrelated research (Peterson-Merunka, 2014). Convenience sampling takes place frequently via the Internet through the instrument of online questionnaire (SueRitter, 2012). In the case of my sample, social-media-based student groups as well as snowball technique were used in order to spread the questionnaire. It can be suspected that those students who self-selected to respond the survey had already had an interest in the topic thereof (i.e. fashion); so, it can be considered that - as it happens with convenience samples in general - the results overestimate the concern with the researched phenomena (Schonlau et al., 2002).

In connection with the sample size of convenience samples, the literature offers several recommendations (Sue-Ritter, 2012), which I tried to follow: sample sizes to range between 30 and 500; once their range is between 30 and 500 , respondents should cover approx. $10 \%$ of the researched population. In the case of Babeş-Bolyai University, the number of students attending solely the BA and MA courses in 2016 was 37,702 (Raportul rectorului [Rector's Report], 2016), which means that the $10 \%$ rule would mean 3,700 responses. Thus, I applied the recommendation of maximum 500 questionnaires. The final response rate during a one-week period - resulted in 305 valid responses.

The online questionnaire distributed among the students was composed of 26 questions corresponding to the following chapters: 1) socio-demographic background of the respondents; 2) consumption habits in connection with fashion, i.e. frequency and places of buying clothes; 3 ) fashion-related information; 4) brand preference; 5) importance of trends, fashion adoption, and fashion involvement; 6) questions in connection with the sustainable closet. In this article, only the results regarding students' brand preferences are presented in extenso. 
Based on the previously mentioned findings of the international literature, I presupposed that having branded clothes is an important thing for the young respondents, but I also wanted to see the importance they attach to branded clothes relative to other criteria.

Consequently, one item of the questionnaire investigated if the respondents had a favourite fashion brand. I supposed that fast fashion brands will be the most preferred ones. However, it is well-known that fast fashion brands can be separated into various types of brands, some of them being more expensive, others can be considered mid-range, while still others value brands (Ross-Harradine, 2006); therefore, it was interesting to see which types of fast fashion brands are preferred in the case of my sample.

Additionally, the importance of brand was assessed compared to other criteria of clothing choice, e.g. price, print, colour, fabric, and composition. This last item through which the relative importance of brand was investigated is, in fact, an adapted version from Kapferer and Laurent's (1983 - qtd by Beudoin et al., 2003) brand sensitivity measure.

Finally, a question investigated whether trendiness, brands, quality, fitting specific occasions, or being creative are important when selecting clothes to wear.

I was also interested to see if fashion involvement goes hand in hand with brand engagement, i.e. whether consumers for whom fashion is important are more predisposed to having a preference in brands. This relationship would seem rational also from the perspective of spending: fashion-involved consumers tend to spend larger amounts of money on clothes, and this larger amount of spending can be the result of both more frequent shopping and investment in higher-value brands (cf. Goldmsith et al., 2012).

In connection with the importance of brands, I hypothesized that:

- The most popular brands are fast fashion brands.

- Better-informed consumers put greater emphasis on brands.

- Fashion-forward students (early adopters) are more brand-sensitive.

- Consumers who spend larger amounts on clothes are more brand-sensitive.

- Brand preference is an important segmentation criterion and allows the separation of various consumer segments.

Besides the online survey, I followed a qualitative research strategy as well, which took the form of focus groups and aimed at revealing meanings, understandings, and deeper narratives on the topic of fashion - in this case, in connection with fashion brands. The focus-group methodology is advantageous when we intend to study the interaction among participants concerning debated topics; by reacting to each other's opinions, focus groups can produce new or different insights compared to individual interviews (Grant-Stephen, 2005).

I conducted four focus groups with a total of 30 student participants. The groups were heterogeneous in terms of gender, students' specializations, or year 
of enrolment. The author of the article was the moderator of the groups. The interview guide consisted of questions touching upon students' narratives in terms of their fashion involvement, fashion consumption, brand preferences, etc. Here, only the results regarding brand-related narratives are presented in detail. The analysis of the focus-group data was interpretative.

\section{Results and Discussions}

\section{Students' Brand Preferences}

According to the results of frequency, $64 \%$ of the sample $(66 \%$ of the men and $65 \%$ of the women) said they had a favourite brand. The list of the favourite brands (Figure 1) reveals the unequivocal preference for fast fashion brands: the brands owned by the Inditex company (with a better representation of the costlier Zara and Massimo Dutti but also Bershka and Stradivarius) are the most preferred brands in the sample, especially among women. Next comes H\&M. In the case of male students, sports brands such as Nike, Adidas, or Columbia are a bit more preferred than the previously mentioned fast fashion brands. Prêt-à-porter brands such as Armani Jeans, Versace Jeans, Guess, Tommy Hilfiger, etc. are preferred by $10 \%$ of the sample, while the preference for luxury brands remains very sporadic. In this respect, we can subscribe to those considerations of the international literature (e.g. Joung, 2014) which argue that fast fashion brands are the most preferred brands among the youth because such clothes reflect actual trends, and the low price of fast fashion items is affordable for the youth.

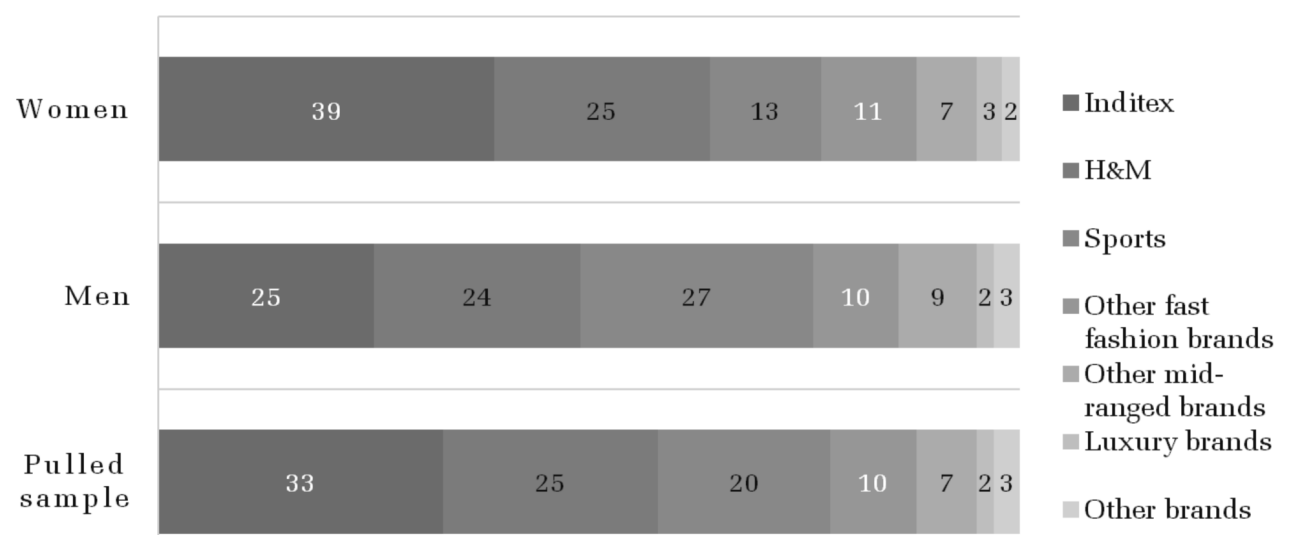

Source: author's graph

Figure 1. The most preferred fashion brands (\%) 
Regarding the economic affordability of fast fashion products, it must be, however, emphasized that in the case of our sample (which, according to the results, spends approx. $46 \mathrm{EUR} /$ month on clothing items), fast fashion products (at least those from the actual collections) might represent a heavy burden. That is why students rely on a compromise: their preferred fast fashion brands are usually bought from outlet/second-hand shops, i.e. from the most preferred sites of shopping (Nistor, 2019).

The importance of brand was assessed also relatively, i.e. compared to other intrinsic (colour, print, quality of the material) and extrinsic (price) attributes of the clothing. For this purpose, the so-called brand-sensitivity item was used (Kapferer-Laurent, 1983 - qtd by Beudoin et al., 2003): respondents were asked on a 5 -point Likert scale (ranging from $1=$ not important at all to $5=$ very important) to indicate the importance of these five criteria in buying clothes.

The relative importance of brand in choosing clothing items shows that compared to other cues brand is a less important criterion of clothing choice. The colour, print, quality of the clothing, fabric, and the price of the clothing seem to count more when students decide to buy a piece of clothing (Figure 2). These findings are in line with previous findings of Kelemen-Erdős and Kőszegi (2017), who in a Hungarian sample showed that in the context of a huge preference for fast fashion brands the role of brands is indeed important for certain consumer segments, but the majority of youngsters base their purchase decisions on other aspects than the brand of the product, and youngsters usually place great emphasis on the price of the products. With other words, as far as students choose standard fast fashion products, they usually judge other aspects of the clothing than their brand.

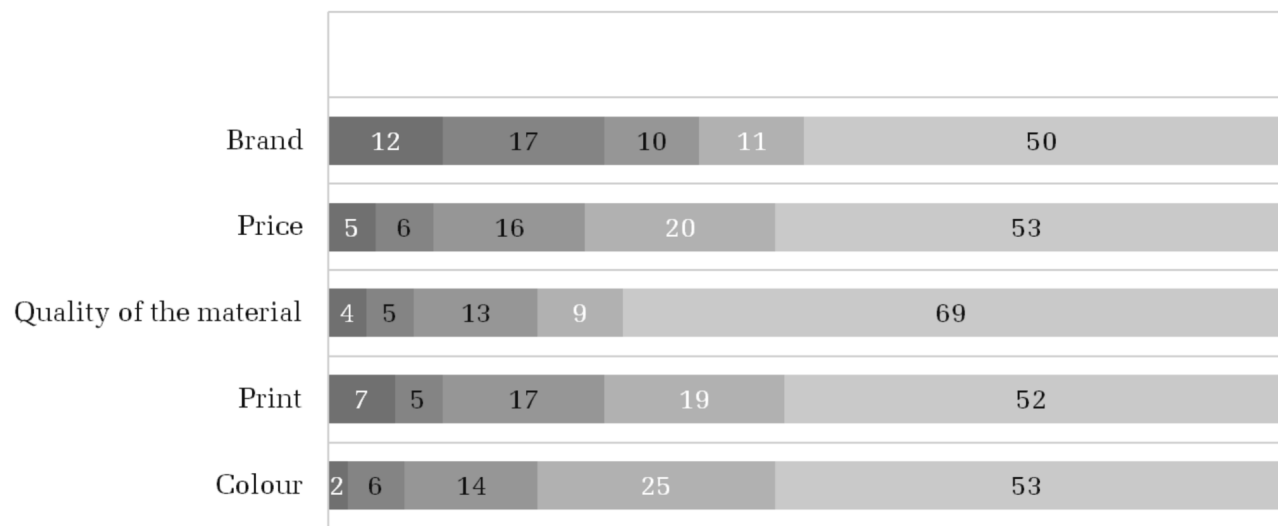

not important at all $\backsim$ not important $\backsim$ more or less important $\backsim$ important $\llbracket$ very important

Source: author's graph

Figure 2. The relative importance (\%) of the five criteria in clothing choice 
The comparison of scale means between men and women shows that there are no differences in terms of the importance of the brand criterion; however, there was revealed a significant difference in terms of the importance of colour, this criterion being significantly more important $(\mathrm{t}=-2.172 ; \mathrm{df}=302 ; \mathrm{p}<0.05)$ for women (Mean = 4.33; Std. dev. = 0.99) than for men (Mean = 4.07; Std. dev. =1.02). Another significant difference was revealed in terms of the price criterion, the price of the clothing being significantly more important $(\mathrm{t}=-2.053 ; \mathrm{df}=302 ; \mathrm{p}<0.05)$ for women $($ Mean $=4.23$; Std. dev. = 1.17) than for men (Mean = 3.95; Std. dev. =1.12). This last finding has to do, probably, with women's more frequent buying behaviour. The results of the survey showed that female students shop clothes significantly more frequently than male students (i.e. women have a higher involvement in apparel shopping - O'Cass, 2004), so they need to make compromises on the price of the products unless they want to reduce their shopping frequency.

Students were asked to indicate the approx. amount of money they spend on clothes in a month. The results show that students spend nearly $215 \mathrm{RON}$ in a month (approx. 46 EUR) on clothing purchases (Mean: 214.74; Minimum: 10; Maximum: 1,000; Std. dev.: 193.43). There is a positive relationship between the importance of brand and the money spent on clothes $(\mathrm{r}=0.214 ; \mathrm{p}<0.001)$, showing that those who spend more money on clothes are more brand-sensitive.

The level of information on fashion was determined by asking respondents to self-rate this item on a 5-point Likert scale. Half of the respondents (51\%) consider themselves as well- or very well-informed in terms of fashion. The mean score is 3.47 (Std. dev.: 1.01), and the results of the $t$-tests $(t=0.674 ; \mathrm{df}: 302 ; \mathrm{p}>$ 0.05) show that there is no significant difference between the subjectively rated information level of women (Mean: 3.44, std. dev.: 1.074) and that of men (Mean: 3.52; Std. dev.: 0.917). A significant, positive correlation was shown between the level of information and brand sensitivity $(r=0.345 ; \mathrm{p}<0.001)$ as well. That is, those students who are - subjectively - more involved in fashion are more sensitive about the brand of the products.

Students were asked to indicate which of the following is their most favourite site of shopping: malls, outlet/second-hand shops, online shops, or other shops. The results are the following: outlets/second-hand shops are preferred the most $(37 \%)$, followed by malls $(33 \%)$, other offline shops other than malls and outlets (25\%), online shops (13\%), and do not know (2\%). The ANOVA analysis suggests that the mean importance of brand differs significantly among the sites of shopping $[\mathrm{F} 3,300=10.184 ; \mathrm{p}<0.001]$. Those who prefer to shop in secondhand shops/outlets are significantly less brand-sensitive (Mean $=3.19$; Std. dev. $=1.62)$ than those who prefer to shop in malls (Mean $=4.19$; Std. dev. $=1.39$ ) or in online shops (Mean $=4.14$, Std. dev. $=1.18$ ).

What concerns the contribution of five different criteria - including the brand of the product - in the definition of well-dressed, the results are presented in 
Figure 3 below. These results show that having branded clothes is less important than the other four criteria in order to be well-dressed.

To have creatively composed outfit

To fit the occasion
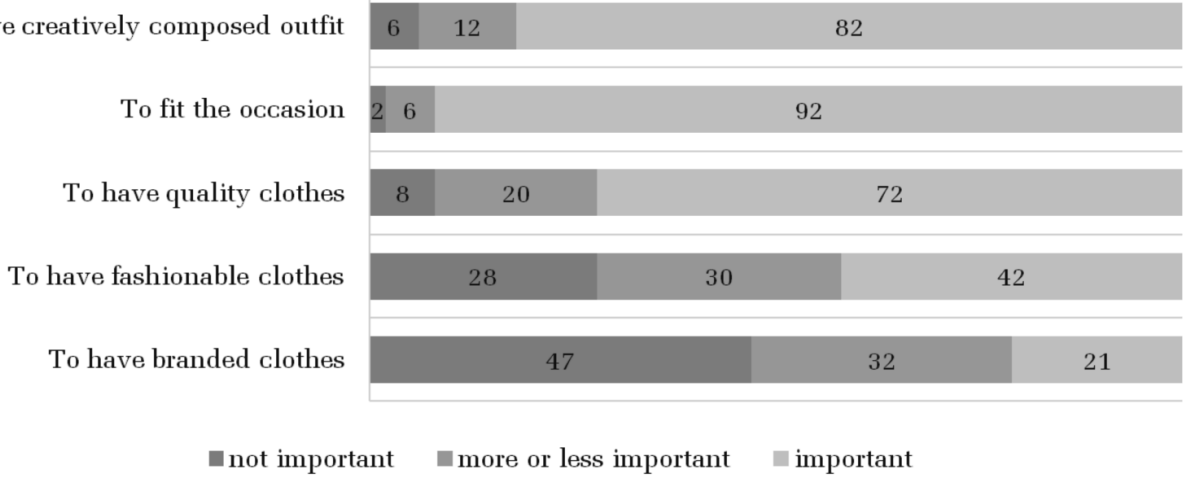

Source: author's graphs

Figure 3. The importance of the five criteria (\%) in the definition of being well-dressed

The amount of money spent on clothes positively correlates with each of the five criteria of being well-dressed, including the role of brands ( $\mathrm{r}=0.341$; $\mathrm{p}<0.001)$. The frequency of shopping correlates significantly only with brandsensitivity ( $r=0.212 ; \mathrm{p}<0.001)$ and fashionability $(r=0.245 ; \mathrm{p}<0.001)$, and the same is the case with the self-rated level of information $(r=0.253$; $p<0.001$ in the case of brand and $r=0.321 ; p<0.001$ in the case of fashionability).

The results resemble a typical situation for a young population, as it was already assessed in the international literature: brand is not a primary criterion of clothing choice for the youth; however, there might be specific segments (e.g. fashion-involved, economically better-off or, on the contrary, economically less privileged, in whose cases brands can be signs of materialistic worldviews and prestige consumption in the form of a compensation) for whom it represents a crucial criterion either in the form of self-expression or conspicuous consumption (e.g. Goldmsith et al., 2012; Parment, 2013; Kelemen-Erdős-Kőszegi, 2017).

In order to measure fashion adoption in my convenience sample, I borrowed an item from Tigert et al.'s (1976) Fashion Involvement Index. More specifically, respondents were asked to say whether they adopt a new trend of fashion before, in the same time, or later than their colleagues/friends. The purpose was that with the help of this item to group respondents in three specific categories: early adopters, late majority, and late adopters (cf. Rogers, 1983). The frequency distribution in the sample was the following: $13 \%$ early adopters, $45 \%$ early majority, $37 \%$ late majority, $5 \%$ do not know. In general, brand-sensitivity is a common phenomenon in the case of fashion-forward respondents (i.e. early 
adopters and early majority) as otherwise suggested by the results synthetized in Table 1, which show the relative importance given to brand across three different groups of fashion adopters.

Table 1. The mean importance of the five criteria of clothing choice and that of the five criteria of well-dressed across the three fashion adoption groups (ANOVA analysis)

\begin{tabular}{|c|c|c|c|c|}
\hline Scale means & $\begin{array}{c}\text { Early } \\
\text { adopters }\end{array}$ & Late majority & $\begin{array}{c}\text { Late } \\
\text { adopters }\end{array}$ & $\mathbf{F}$ \\
\hline \multicolumn{5}{|c|}{ Criteria of clothing choice } \\
\hline The role of colour & $3.97(0.96)$ & $4.35(0.87)$ & $4.06(1.15)$ & $\mathrm{F}(2.287)=3.514 ; \mathrm{p}<0.05$ \\
\hline The role of print & $3.48(1.25)$ & $3.86(1.39)$ & $4.26(1.06)$ & $\mathrm{F}(2.287)=3.414 ; \mathrm{p}<0.05$ \\
\hline $\begin{array}{l}\text { The role of material } \\
\text { quality }\end{array}$ & $4.52(0.99)$ & $4.16(1.23)$ & $4.10(1.18)$ & $\mathrm{F}(2.287)=4.222 ; \mathrm{p}<0.05$ \\
\hline The role of price & $3.67(0.97)$ & $4.05(1.18)$ & $4.19(1.18)$ & $\mathrm{F}(2.287)=2.890 ; \mathrm{p}<0.05$ \\
\hline The role of brands & $4.13(1.28)$ & $3.95(1.41)$ & $3.56(1.58)$ & $\mathrm{F}(2.287)=3.449 ; \mathrm{p}<0.05$ \\
\hline \multicolumn{5}{|c|}{ Criteria of being well-dressed } \\
\hline The role of brands & $3.95(1.29)$ & $3.17(1.27)$ & $3.02(1.45)$ & $\mathrm{F}(2.287)=6.952 ; \mathrm{p}<0.05$ \\
\hline $\begin{array}{l}\text { The role of } \\
\text { fashionability }\end{array}$ & $3.64(1.58)$ & $3.03(1.35)$ & $2.96(1.45)$ & $\mathrm{F}(2.287)=3.491 ; \mathrm{p}<0.05$ \\
\hline The role of quality & $4.29(0.86)$ & $4.14(1.03)$ & $4.04(1.09)$ & $\mathrm{F}(2.287)=1.225 ; \mathrm{p}>0.05$ \\
\hline $\begin{array}{l}\text { The role of fitting the } \\
\text { occasion }\end{array}$ & $4.46(0.72)$ & $4.41(0.69)$ & $4.42(0.69)$ & $\mathrm{F}(2.287)=0.956 ; \mathrm{P}>0.05$ \\
\hline $\begin{array}{l}\text { The role of creative } \\
\text { outfits }\end{array}$ & $4.48(0.64)$ & $3.93(0.93)$ & $3.85(1.16)$ & $\mathrm{F}(2.287)=5.995 ; \mathrm{p}<0.05$ \\
\hline
\end{tabular}

It turns out that early adopters of fashion are significantly less sensitive to colour, print, and price when they choose an item of clothing; however, the quality of the material of which the item of clothing is made and the brand of the item count significantly more for them than for the other fashion adoption groups. On the basis of these results, it is possible to confirm the presupposition according to which early adopters are less price-conscious but at the same time more brand-sensitive than the other fashion adoption groups. This finding is in line with those assessed in the international literature (e.g. Beaudoin et al., 2003; Cardoso et al., 2010).

We can conclude that the students are only more or less brand sensitive. Indeed, $60 \%$ of the sample do have a favourite fashion brand, and much of these seem to be fast fashion brands. However, it also happens that brand is a less important criterion of clothing choice than the intrinsic attributes of clothes and their price. The same results are provided in terms of brands when the criteria of being well-dressed are examined. Here, fitting the occasion and having a creatively composed outfit seem to be more important than having branded and fashionable outfits. 
However, it was also demonstrated that those students who are more involved in fashion are early adopters of fashion trends, have higher budgets to spend on clothes, prefer to acquire their clothes from malls, and are more brand-sensitive. Brand sensitivity can thus be a segmentation criterion: it can separate between fashion-involved and less price-sensitive students on the one hand and between later adopters, more price-sensitive students on the other hand.

\section{Brand-Related Narratives}

The results of the online survey have already shown students' unequivocal preference for fast fashion brands. On the basis of the focus groups' narrative, there can be revealed three major groups/tendencies in connection with brand preference: 1) participants who have an unequivocal preference for a specific brand, 2) participants who have a favourite brand only in the case of a specific type of clothing item, and 3) participants who do not have a favourite brand.

The first case resembles those respondents who were not disappointed by their favourite brand; for them, these brands are the source of pleasure and satisfaction. So, the narratives from this group do not refer to fast fashion as a form of cheap, lower-quality fashion (e.g. Gabrielli et al., 2013; Joung, 2014). On the contrary, students characterize their preferred brands using positive terms such as "stylish", "high-quality”, "unique”, "cool”, "comfortable”, "affordable”, "young”, "specific", "well-cut", etc. These narratives can be considered a form of hedonistic approach on fast fashion brands; these brands provide gratification, fulfilment in terms of fashionability and style and offer opportunities for unique combinations. This stream of the narratives is in line with those previous findings of the literature which contend that fashion- and brand-conscious shoppers practise hedonistic consumption, and they take away fun and pleasure from the consumption of (fast) fashion brands (Park-Sulivan, 2009; Eastman et al., 2012; Bahng et al., 2013; Colucci-Scarpi, 2013).

I'm in favour of Zara. I think it is really beautiful, they make very beautiful clothes, and I do not agree that they do not have quality. All that I have from Zara are in perfect condition. I just love Zara... It is very different from the rest... They have stylish clothes. It happened that I switched to other brands, but I was not satisfied. Zara is much better than all those other brands... The clothes are not cheap... Or not so cheap, but their quality compensates the prices.

I am also a fan of Zara, but I like H\&M as well. When I have money, I buy from Massimo Dutti as well. These three are my favourites... Each of them 
has a particular style, I do not think that these brands are the same. Zara is stylish, Massimo is high class, H\&M is very comfortable for T-shirts, jeans, and things like that.

I like all of these, these are cool brands... But that's true that you have to select among the products. Now everybody goes to these shops... A few years ago, it was different. When you bought something from Zara, you were very different... I mean, you were over the rest... Now, everyone goes to the mall and buys Zara. It's more difficult now to have a unique outfit.

The question of homogeneity through fast fashion products was also raised during the group discussions, but the respondents considered that they can be unique even if they are wearing the same brands of the same products from a particular brand as other consumers do. The key to being different from the rest is the originality of combinations. In this respect, they refer to the role of individual adoptions, to the so-called bricolage (Barnard, 2002), through which there can be constructed various styles, images, and meanings by using the same dresses.

I [...] think that it is very much up to you. How you wear that dress. What accessories you use, how you combine different elements...

Through a single new piece I am not going to look the same as others... Moderation is the key...

You buy something and then combine it with your already existing clothes... It is a way of re-creation, in fact.

Even if the literature considers fast fashion brands as cheap products, the respondents tend to share the view that these brands have quite high prices for students' pockets; so, they employ various strategies in order to acquire their favourite brands. Thus, even if they cannot afford to buy these brands from the high street, malls, or from online shops, the faithful, hedonistic consumers of fast fashion brands make compromises and look for such brands in outlets, secondhand shops or buy them from other cities in the country or from abroad. In such cases, fast fashion brands become important not (only) for their trendiness (after all, the interviewees do not buy the latest trend in such situations) but for their specific style and cut or for their value of signalling a certain status or image.

I also go to the mall and usually cannot resist buying. But I cannot afford to buy a coat, so I buy cheaper items like tops...

My strategy is to find my preferred brands in an outlet or in a second-hand shop, but mostly in outlets. When I go to such shops, I typically look at the labels. If something I like it is not my favourite brand, I hardly buy it. 
The case of those respondents who stick with a specific brand only in the case of a certain clothing item, most frequently shoes, resembles the type of utilitarian shoppers (Park-Sullivan, 2009; Bahng et al., 2013). These consumers associate certain brands with higher levels of durability, comfort, aesthetics, or status (Cardoso et al., 2010). Thus, in the case of those products which are important for them (i.e. high-involvement products - O'Cass, 2004), students remain faithful to a particular brand, while in terms of other clothing items they are switching between brands or do not give importance to the role of the brand criterion.

I think that in what regards your everyday clothes, brands are not so important. I do not spend large amounts on my everyday clothes. But for my occasional outfits I spend a lot because I like them to look good and have a higher quality.

The same is here, but I would say there are several categories for me in which case the brand is important: my shoes, my suits, and my watch. The rest is not so important. But people judge you on the basis of these things.

The third group comprises three specific categories: 1) Respondents who do not have a favourite brand: these interviewees are usually impulse buyers who - once the style or the price of the product is appealing - decide to buy the product regardless of its brand. 2) The other group is made up of those consumers who do not have a favourite brand because they consider that brands are not affordable for them, and thus the low price of a product becomes more important than the brand (cf. price-conscious shoppers - Loureiro-Breazeale, 2016). 3) A third group is made up of those consumers who have a critical attitude towards brands in general either because they were disappointed by their previously preferred brands or because of their critical attitudes towards fast fashion or consumerism. The following excerpt from a focus group gives examples for each of these situations:

I had favourite brands, but the products then started to become very low quality, so it was not economically sustainable to buy from that brand anymore... I have become more attentive since then, and so I do not necessarily choose the product of a certain brand but the quality of a product, regardless of its brand.

We all, I think, have bad experiences not only with fast fashion brands but with brands in general. So, I have become more critical. I tried to buy clothes based on documentation. I have read about brands, products, their philosophy, and if they convince me, then I try to buy from such brands. I am a more difficult case. I am very critical about my clothes. I read a lot 
about certain brands, and I like to have brands which are more specific. I do not like these brands... All those things that were mentioned previously... I am not that kind of girl... I admit that there are girls who look good in the brands from the mall... I do not like to look the same... Then I am searching... I have several brands which I like or admire; I do not necessarily have clothes from them... But I agree with their philosophy.

As a conclusion for youngsters' brand-related narrative, we can mention that the fact that they can hardly see beyond fast fashion is typical for their generation; however, the finding that the participants do not constitute a monolithic group and there are also interviewees who are critical, resistant, or more attentive in terms of what they buy shows that the attitude towards fashion brands is much more diverse than it would seem at first sight. It is also important to mention that even if the majority are faithful to fast fashion brands, youngsters see these brands or clothing items in the form of a stylistic attempt rather than in the form of a fashion statement. They are looking for these brands not necessarily in order to buy the latest trends but in order to buy an item (even from a previous collection - cf. the buying of certain brands from outlets) from a fashionable brand in order to integrate it among their own clothing items. From this perspective, fast fashion brands appear as a kind of status symbol for economically less better-off students: once a piece of branded clothing is integrated into a commonsensical outfit, youngsters pretend that their outfit becomes much more valuable, nicer, stylish, cool, and distinct. This is a paradoxical situation: interviewees pretend that they can become unique through similar clothes as far as they do not wear these clothes in similar combinations.

\section{Concluding Remarks}

The results of my mixed-method study conducted among students in Cluj-Napoca (Romania) with the aim of revealing students' sensitivity regarding fashion brands showed that the majority of the respondents have a favourite brand, and most of these are fast fashion brands. Even if the literature has many arguments in the direction of blaming these brands for their low quality, poor environmental performance, homogeneity, etc. (Joy et al., 2012; Gabrielli et al., 2013), the majority of the respondents see these brands through the lenses of prestige: they think that such brands can bear quality, durability, and, above all, they are perceived as cool brands. Youngsters speak about these brands in appreciative ways and associate them with success, prestige, and social status. These are indicative for students' materialistic views on fashion and brands. It seems that in the context of relative economic scarcity owning a (fast fashion) brand is a signal of prestige 
(cf. conspicuous consumption), and so it is worth the effort of hunting for such brands at low prices at sales or in second-hand shops. Thus, brands are important building blocks of the image and social status and are signals of success, as the findings of the focus-group research suggest as well (cf. Eastman et al., 2012).

Through the narratives of focus groups, it was possible to reveal the reason for preferring such brands: besides offering a way of affiliation to global lifestyles, fast fashion brands are mostly viewed as qualitative, prestige brands. Students manifest discourses which are against the literature's approach on fast fashion brands as low-quality, environmentally problematic brands (e.g. Joy et al., 2012). This finding can be interpreted also from the viewpoint of limited budgets and materialistic values: for the youngsters, fast fashion brands are the symbols of global, cool lifestyles as seen in social media, and they thus feel urged to buy these brands because in this way they can become adherents of global culture and wearers of cool, prestige brands. Albeit they reject the conspicuous wearing of branded clothes, they recognize that wearing brands can be a signal of a higher social status, of success. Besides such hedonistic attitudes towards fast fashion, the narratives revealed two other segments which reveal more rational attitudes on brands. In one of these, brands count only to a certain degree, usually in the case of some items (mostly shoes); in the other group, which resembles mostly the case of price-conscious shoppers, criteria other than brand are important; these respondents try to guide their shopping based on the criterion of price or on criteria of anti-consumerist attitudes.

The study also revealed that fast fashion brands are mixed and matched in particular outfits and allow the construction of different yet fashionable and accepted outfits through which youngsters can reinterpret themselves and their image (see Gabrielli et al., 2013). The focus groups succeeded in revealing more critical discourses as well: such (a few) participants see fast fashion brands as very homogenous, superficial, and low-quality clothing and are looking for individual brands and styles. Even if such narratives are relatively rare, they are sending out important messages about the seeds of a counter-culture amongst the dominance of fast fashion brands and open an avenue for more diverse ways of image building.

The survey also showed that brands count less than other aspects of clothing when it comes to buying apparel: the colour, print, fabric, and price of the items are much more important than the brand of the products, and these can be quoted as signals for price-conscious shopping. A further nuance in this respect is that the dressier, more fashion-involved respondents place greater importance on brand and less importance on the other criteria, including price as well. This finding is in line with the international literature (e.g. Goldsmith et al., 2012) and illustrates that the group of early adapters are hedonistic consumers who, once meeting a new, appealing trend, acquire its items from their favourite brands no matter the cost. 


\section{References}

Bahng, Y.-Kincade, D. H.-Yang, J. J. (2013). College Students' Apparel Shopping Orientation and Brand/Product Preferences. Journal of Fashion Marketing and Management 17(3): 367-384.

Bakewell, C.-Mitchell, V. W. (2003). Generation Y Female Consumer DecisionMaking Styles. International Journal of Retail and Distribution Management 31(2): 95-106.

Barnard, M. (2002). Fashion as Communication. London: Routledge.

Barton, C.-Fromm, J.-Eagan, C.-2012. The Millennial Consumer: Debunking Stereotypes. The Boston Consulting Group.

Batey, M. (2008). Brand Meaning. New York: Routledge.

Baudrillard, J. (1970/1998). The Consumer Society. Myths and Structures. London: Sage.

Beaudoin, P.-Lachance, M. J.-Robitaille, J. (2003). Fashion Innovativeness, Fashion Diffusion and Brand Sensitivity among Adolescents. Journal of Fashion Marketing and Management 7(1): 23-30.

Cardoso, P. R.-Tsourvakas, G.-Santos, J. (2005). Information Sources and Clothing Brands Consumption in Mediterranean Countries. A Qualitative Study of Attitudes and Behavior of the Greek and Portuguese Young Consumers. $<$ http://www.bocc.ubi.pt/pag/cardoso-tsourvakas-santos-information-sources. pdf> (Accessed on: 3 October 2019).

Colucci, M.-Scarpi, D. (2013). Generation Y. Evidences from the Fast-Fashion Market and Implications for Targeting. Journal of Business Theory and Practice 1(1): $1-7$.

Crane, D. (2000). Fashion and Its Social Agendas. Class, Gender, and Identity in Clothing. Chicago: University of Chicago Press.

Eastman, J. K.-Iyer, R.-Thomas, S. P. (2012). The Impact of Status Consumption on Shopping Styles. An Exploratory Look at the Millennial Generation. The Marketing Management Journal 23(1): 57-73.

Fernandez, P. R. (2009). Impact of Branding on Gen Y's Choice of Clothing. The Journal of the South East Asia Research Centre for Communication and Humanities 1(1): 79-95.

Fletcher, K. (2008). Sustainable Fashion and Textiles. Design Journeys. London: Earthscan.

Franzen, G.-Moriarty, S. (2009). The Art and Science of Branding. Armonk: M. E. Sharpe.

Gabrielli, V.-Baghi, I.-Codeluppi, V. (2013). Consumption Practices of Fast Fashion Products: A Consumer-Based Approach. Journal of Fashion Marketing and Management 17(2): 206-224. 
Gliner, J. A.-Morgan, G. E.-Leech, N. (2009). Research Methods in Applied Settings. New York: Routledge.

Goldsmith, R. E.-Flynn, L. R.-Clark, R. A. (2012). Materialistic, Brand Engaged and Status Consuming Consumers and Clothing Behaviors. Journal of Fashion Marketing and Management 16(1): 102-119.

Howe, N.-Strauss, W. (2000). Millennials Rising. The Next Great Generation. New York: Vintage Books.

Joung, H-M. (2014). Fast Fashion Consumers' Post-Purchase Behaviours. International Journal of Retail and Distribution Management 42(8): 688-697.

Joy, A.-Sherry, J. F.-Venkatesh, A.-Wang, J.-Chan, R. (2012). Fast Fashion, Sustainability and the Ethical Appeal of Luxury Brands. Fashion Theory 16(3): 273-296.

Kawamura, Y. (2011). Doing Research in Fashion and Dress. An Introduction to Qualitative Methods. Oxford: Berg.

Kelemen-Erdős, A.-Kőszegi, Zs. (2017). Fast fashion márkák szerepe a fiatalok önkifejezésben. Vállalkozásfejlesztés a XXI. században. <http://kgk.uniobuda.hu/sites/default/files/17_KelemenErdosAniko_KoszegiZsuzsa.pdf> (Accessed on: 3 October 2019).

Knittel, Z.-Beurer, K.-Berndt, A. (2016). Brand Avoidance among Generation Y Consumers. Qualitative Market Research 19(1): 27-43.

Loureiro, S. M. C.-Breazeale, M. (2016). Pressing the Buy Button. Generation Y's Online Clothing Shopping Orientation and Its Impact on Purchase. Clothing and Textiles Research Journal 34(3): 1-16.

Nistor, L. (2019). The Case of Omni-Channel Consumers. A Qualitative Study Regarding Students' Clothing Consumption Habits. Postmodern Openings 10(3): 44-71.

O'Cass, A. (2004). Fashion Clothing Consumption: Antecedents and Consequences of Fashion Clothing Involvement. European Journal of Marketing 38(7): 869882.

Park, H.-Sullivan, P. (2009). Market Segmentation with Respect to University Students' Clothing Benefits Sought. International Journal of Retail and Distribution Management 37(2): 182-201.

Parment, A. (2013). Generation Y vs. Baby Boomers. Shopping Behavior, Buyer Involvement and Implications for Retailing. Journal of Retailing and Consumer Services 20(2): 189-199.

Pentecost, R.-Andrews, L. (2010). Fashion Retailing and the Bottom Line. The Effects of Generational Cohorts, Gender, Fashion Fanship, Attitudes and Impulse Buying on Fashion Expenditure. Journal of Retailing and Consumer Services 17: 43-52.

Peterson, R. A.-Merunka, D. R. (2014). Convenience Samples of College Students and Research Reproducibility. Journal of Business Research 67: 1035-1041. 
Popa, A.-Pelau, C. (2016). Diferențe în percepția brandurilor de îmbrăcăminte în funcție de generație. Industria Textilă 6: 260-264.

Raportul Rectorului, 2016. <http://www.ubbcluj.ro/ro/infoubb/documente_ publice/files/raport-rector/Raport_Rector_2016.pdf> (Accessed on: 3 October 2019).

Rhee, J.-Johnson, K. K. P. (2012). Predicting Adolescents' Apparel Brand Preferences. Journal of Product and Brand Management 21(4): 255-264.

Rogers, E. M. (1968/1983). Diffusion of Innovation. New York: The Free Press.

Ross, J.-Harradine, R. (2010). Value Brands: Cheap or Trendy? An Investigation into Young Consumers and Supermarket Clothing. Journal of Fashion Marketing and Management 14(3): 350-366.

Sandu, D.-Stoica, C. A.-Umbres, R. (2014). Tineri în România. Griji, aspirații, atitudini şi stil de viață. Bucharest: Friedrich Ebert Stiftung.

Schonlau, M.-Fricker, R. D. Jr.-Elliott, M. (2002). Conducting Research Surveys via E-mail and the Web. Santa Monica: RAND.

Segran, E. (2016). Your Guide to Generation Z. The Frugal, Brand-Wary, Determined Anti-Millennials. Fast Company 09.08.2016.

Sue, V. M.-Ritter, L. A. (2012). Conducting Online Surveys. Los Angeles: Sage. Tigert, D. J.-Ring, L. J.-King, C. (1976). Fashion Involvement and Buying Behavior. A Methodological Study. Advances in Consumer Research 3: 46-52.

Yarrow, K.-O'Donnell, J. (2009). Gen BuY: How Tweens, Teens, and TwentySomethings Are Revolutionizing Retail. San Francisco: Jossey-Bass. 